\title{
Investigating the Impact of Teachers' Interaction Strategies on Enhancing EFL Students' Contributions at King Abdulaziz University: A Classroom Discourse Analysis
}

\author{
Hanaa Abdullah Al-Ghamdi \\ English Language Institute, King Abdulaziz University \\ PO Box 80200, Jeddah, 21589, Jeddah, Saudi Arabia \\ E-mail: haaalghamdi@kau.edu.sa
}

Dr. Abdullah Al-Bargi

English Language Institute, King Abdulaziz University

PO Box 80200, Jeddah, 21589, Jeddah, Saudi Arabia

E-mail: aalbargi@kau.edu.sa

Received: August 20, 2017 Accepted: September 2, 2017 Published: September 4, 2017

doi:10.5296/ijele.v5i2.11801 URL: https://doi.org/10.5296/ijele.v5i2.11801

\begin{abstract}
This qualitatively designed study investigated the interaction strategies employed by English as a Foreign Language (EFL) teachers to enhance students' contributions during classroom interaction, as well as exploring the impact of these strategies on Saudi EFL students' verbal discourse in English Language Institute (ELI) at King Abdulaziz University. Nine teachers, along with their respective students participated in this study recording a ten-hour video and audio recordings representing the study's primary data. All recorded (video and audio) data was transcribed and an Interaction Analysis (IA) approach was adopted for analyzing teachers' and students' classroom discourse. The findings indicated that EFL teachers attempted to enhance students' contributions in various ways, and that the strategies used by teachers had varying impact on students' classroom discourse. In addition, findings suggested that students' verbal discourse could be developed with a relatively higher degree of teachers' extended strategies and use of backchannels. Pedagogical implications, recommendations, and suggestions for further research were presented at the end of this study.
\end{abstract}

Keywords: Interaction strategies, classroom discourse, qualitative design, EFL, Saudi Arabia 


\section{Introduction}

In second (L2) and foreign language (FL) classrooms, successful students' language learning is the ultimate goal that EFL teachers and students strive to accomplish. At the same time, language is the tool through which learning can possibly be achieved. In the last couple of decades of the twentieth century, constructivism directed attention towards the effect of learners' interaction with others, and their ability to use language appropriately to convey and interpret messages in different contexts (Adegbile \& Alabi, 2005; Brown, 2000). Vygotsky, the constructivist pioneer, and his successors had been largely credited for the current focus given to the relationship between socializing and learning. Hall and Walsh (2002) argue that "schools are important sociocultural contexts" (p.186) where the instructional environment is formed through teacher-student interaction, which is a significant factor in creating an effective learning environment and for developing learners' language ability (Aimin, 2013). Thus, discourse analysis (Sinclair \& Coulthard, 1975) has been conducted in the classroom in order to evaluate teacher and student output, interactional practices, classroom procedures, types of relationships between teachers and students, and used to describe influential non-language factors; taking into consideration both cultural and contextual influences (Yoshida, 2008). In the last two decades, teacher talk time (TTT) in the EFL classroom was encouraged to be reduced or kept to a minimum in order to allow more class-time opportunities for students to speak and develop their language and as a result, some researchers analyzing classroom discourse focusing on the amount of TTT affirm that TTT is a major factor for the effectiveness of classroom interaction and language learning (Tsui, 1995; Tsui, 1998; Kim and Suh, 2004).

Recently, the interest in studying teacher talk have started to shift from a concern with the quantity of talk, though remained important, to a concern with the quality of teacher talk (Cullen, 1998 and Yanfen \& Yuqin, 2010). Thus, teacher feedback and response to students' contributions and their strategies such as rejecting, repeating, elaborating and reformulating have been found to be critical elements in classroom interaction, as they have a significant effect on students' discourse and classroom interaction (Pei, 2012). Although additional research is required, studies have revealed the effectiveness of some interaction strategies (e.g. increasing wait time, negotiating meaning, extending students' turns) in developing students' classroom discourse and in encouraging their involvement in classroom interaction (Clifton, 2006; Mikkola, 2008; Walsh, 2002, 2006, 2011 \& 2012). As a result, this study specifically focuses on the teacher talk used to modify and enhance learners' contributions and analyzes the manner in which this teacher talk affects the development of students' discourse in the Saudi EFL classroom.

\subsection{Statement of the Problem}

King Abdulaziz University (KAU), English language Institution (ELI) teachers regularly contend that they encounter problems with students' unresponsiveness, reticence, or one-word responses which restrict and limit classroom interaction. In consequence of these issues, this study aims to examine and challenge the role of teachers in assisting students to effectively communicate in the classroom by focusing on the interactional strategies teachers 
employ in a face-to-face classroom interaction in an endeavor to help develop and enhance students' contributions in the EFL classroom (Dagarin, 2004).

\subsection{Significance of the Study}

The current study is hoped to improve the quality of students' oral contributions and increase the amount and complexity of their discourse in the EFL or English as a Second Language (ESL) classroom, to shed light on the relationship between teachers' discourse strategies and students' verbal performance, and to reveal actual language use and the interaction strategies employed by teachers and their impact on students' learning outcomes.

\subsection{Research Questions}

The current study attempts to answer the following research questions:

RQ1: What types of EFL verbal interaction strategies do ELI teachers employ in order to enhance student contributions during classroom interaction?

RQ2: How do teachers' interaction strategies affect students' classroom verbal discourse?

\subsection{Delimitations of the Study}

This study is limited to only one Saudi University in the city of Jeddah. Participants were nine Saudi male EFL classrooms with only two taught proficiency level classrooms: ELI 103 (pre-intermediate) and ELI 104 (intermediate).

\section{Review of the Literature}

\subsection{Theoretical Framework}

\subsubsection{Sociocultural Theory of Learning}

Second Language Acquisition (SLA) has been increasingly influenced by Vygotsky's sociocultural approach to learning and education, in which he stressed the social nature of learning and argued, "Every function in the child's cultural development appears twice, first on the social level, and later on in the individual level, first between people (interpsychological) and then inside the child (intrapsychological)" (Vygotsky, 1978, p.57). He claimed that learning, including language learning, occurs when cognitive functions are evolved through interactional activities and social participation.

\subsubsection{Vygotsky's Zone of Proximal Development (ZPD)}

In addition, Vygotsky believed that learning occurs through interaction, which should be within the learners' zone of proximal development (ZPD) (Nassaji \& Swain, 2000). The ZPD is defined as "the distance between the actual development level as determined by independent problem solving and the level of potential development as determined by problem solving under adult guidance or in collaboration with more capable peers" (Vygotsky, 1978, p. 86). Within the sociocultural theory framework, this research investigates how teachers, through their social interactions, develop students' abilities to communicate in the 
target language within their ZPD by examining the discourse strategies employed for the enhancement of students' contributions (Aljaafreh, \& Lantolf, 1994 and John-Steiner \& Mahn, 1996).

\subsection{Students' Contributions}

For constructivists, learner talk is considered as a tool through which a foreign language can be learned and developed, and students' contributions and participation are thought to be fundamental for learning the foreign language. However, different researchers have investigated the causal factors that have resulted in students' silence or minimal contributions (Tsui, 1996; Liu, 2005). One of the common problems faced by EFL teachers is dealing with unresponsive students who produce minimal one-word responses or who don't respond and contribute at all in classroom discourse (Snell, 1999). As a result, Mohr and Mohr (2007) proposed 'The Response Protocol', which focuses on two key elements: valuation of students' responses and teachers' efforts to scaffold elaboration. Similarly, EFL teachers in Saudi Arabia face similar problems of students' reticence and unwillingness to speak and participate in classroom discussions. For seeking answers, Aljumah (2011), who used the integrative approach, which is a combination of suitable techniques from the four communication skills in addition to sociolinguistics: note-taking and comprehension from listening, discussion from speaking, studying one's textbook from reading, writing-up from both writing and speaking, and finally, found out that students had exhibited a considerable development in their oral skills, and it indicated the usefulness of the integrative approach for overcoming students' participation and interaction reticence in classroom discussions.

\subsection{Classroom Interaction}

\subsubsection{The Significance of Classroom Interaction}

Interaction is the key element in communication, it is, in fact, the heart of communication or what communication is all about (Brown, 2000). As a result, Communicative Language Teaching (CLT) approach, emerged in the early 1970s, focuses on enabling learners to communicate through interaction in the target language (Nunan, 1991). Kramsch (1986) introduced the notion of interactional competence (IC); "the skills and knowledge individuals employ to bring about successful interaction" (p. 367) as a new, way of looking at language education. Walsh (2013) continued the discussion by developing the notion of classroom interactional competence (CIC), which he defined as "Teachers' and learners' ability to use interaction as a tool for mediating and assisting learning" (p. 158). Many researchers have studied classroom interaction and the effect of teacher language use on EFL/ESL students' language development. For example, Johnson (1995), presented a conceptual framework for teachers' and students' face-to-face classroom interactions that shape the dynamics of classroom communication, found out that using more spontaneous patterns of interaction allowed students to participate in the interaction's structure and content; consequently, students discourse was extended. In addition, Shomoossi (2004), who studied Iranian teachers' questioning patterns and their effect on EFL classroom interaction, indicated that teachers ask display questions more frequently than referential questions, and that referential questions produce more classroom interaction. Shomoossi (2004) reported a number of factors that 
impact classroom interaction such as repeating questions, asking low-language-proficiency students a talk-initiating question, and limiting the class to the text book. On the other hand, he found that discussing interesting topics, giving attention and showing interest to students' responses, negotiating meaning, and incorporating humor into the classroom were among the factors that contributed to enhancing the amount of interaction. In an attempt to investigate the interactional patterns of teacher talk (as a facilitator), Clifton (2006), who examined a stretch of naturally-occurring classroom interaction of French EFL learners and their teacher, showed that the teacher was able to encourage learners to develop the topic under discussion by using backchannels; short utterances, such as 'uhu' and 'yeah'. Moreover, Shamsipour and Allami's (2012) analysis of three EFL Iranian teachers' classroom discourse, based on the self-evaluation of teacher talk (SETT) framework, showed the importance of the relationship between classroom interaction and language learning in EFL contexts. As such, students' contributions, negotiating meaning, scaffolding, extending learner turns, asking referential questions and choosing interesting topics, tend to encourage learner talk and develop classroom interaction. In contrast, excessive teacher control of the interaction, explicit evaluation, question repetition, interruption and teacher echo tend to have a negative impact on students' classroom interaction.

\subsubsection{IRF/IRE Interaction Pattern}

Various studies have been conducted on classroom dynamics and interaction patterns during face-to-face classroom interaction between teachers and students. Mehan (1979), who comprehensively analyzed the structure and sequence of interaction based on a year of videotaped observations of different classroom lessons, revealed that the most recurrent pattern of interaction is a sequence of an initiation, most frequently by the teacher, followed by a reply, most often by a student, which in turn is followed by an evaluation. Moll (1992) further asserted that instructional discourse is characterized by the initiation-reply-evaluation sequence. The three-part sequence known as the IRE, Initiation-Response-Evaluation, or IRF, Initiation-Response-Feedback is a typical structure of all classroom discourse (Lemke, 1990; Walsh 2013; Wells, 1999). While some researchers believe that the IRF/IRE exchanges support learning and guide instructional goals (Mercer, 1992; Nassaji \& Wells, 2000; Wells, 1999), others argue that it hinders students' learning and limits their classroom interaction (Lemke, 1990; Nikula, 2007; van Lier, 1988; Walsh, 2002). Mercer (1992), for example, pointed to the benefits of the IRF structure as an effective means by which teachers can engage students, monitor their knowledge and check their comprehension. Similarly, Nassaji and Wells (2000) explained how it can allow teachers to check students' grasp of taught material and to engage learners in the co-construction of knowledge. However, critics of the IRF structure say that it promotes illusory participation (Lemke, 1990). Nikula (2007), argued that it does not provide students with sufficient space to develop their ideas and participate in extended talk. Moreover, Van Lier (1988), pointed out that it does not encourage students' initiation and repair, while Walsh (2002) stated that it restricts learning opportunities and minimizes learner involvement as it is dominated by teacher talk (Walsh, 2002). Cullen (2002) and Nassaji \& Wells (2000) further argued that teachers' follow-up moves have a significant impact on developing students' discourse, thus enhancing the quality of learning. 


\subsubsection{The Importance of Teacher Feedback/Follow-Up Moves}

Teachers' verbal feedback and response on students' answers is a critical element in any educational classroom discourse. Brown and Wragg (2003) suggested that "responding moves are, in a sense, the linchpins of a lesson, because they establish, in the eyes of the pupil, the tone of the lesson" (p. 34). Nassaji and Wells (2000) highlighted the importance of teacher follow-up moves in extending student participation. Furthermore, Walsh (2013) asserted that "a teacher's feedback on a student's contribution is more likely to help learners (cf. scaffolding) and to encourage fuller, more elaborated responses" (p. 44). In his study, Cullen (2002) differentiated between two roles of the F-move, evaluative and what he terms as 'discoursal'. The discoursal F-move focuses on feedback's discoursal role, which is concerned with the content of a student utterance rather than its form, as opposed to in evaluative feedback (Jones, 2011). According to Cullen (2002), both functions of the F move, discoursal and evaluative, are important for supporting learning, since the former helps develop a communicative classroom dialogue between teacher and students where the latter assists students in error correction. He further suggested that teachers have to be skillful in making on-the-spot judgments concerning feedback appropriateness when responding to student contributions.

\subsection{Modifying and Enhancing Students' Contributions}

The ways in which teachers acknowledge, modify, extend and improve students' contributions have been addressed by different researchers using different terms throughout the literature. Mercer (1994) for example, used the term "appropriation" in relation to classroom discourse to describe the manner in which teachers, through their verbal interaction, take students' utterances, modify them and offer them back to the discourse, claiming that this is often done by paraphrasing or constructively recapping what students have said. The importance of such strategies lies in the manner in which teachers' systematically use interaction exchanges to build on and extend students' discourse (Hammonds \& Gibbons, 2005). Furthermore, Jarvis and Robinson (1997) argued that teacher responsiveness can achieve the function of appropriating learners' utterances and modifying them into more appropriate meaning. Similarly, after introducing the notion of shaping learner contribution, Walsh (2013) stated that: "the process of taking a learner's contribution and shaping it into something more meaningful has been termed appropriation" (p.58), indicating the similarity between these two notions in modifying students' utterances into more appropriate and meaningful contributions. All these concepts require teachers to possess capability to accept and improve students' contributions using various strategies in verbal classroom interaction.

\subsection{Impact of Teacher Interaction Strategies on Enhancing Students'Discourse}

Researchers investigating classroom discourse and exploring teacher talk and patterns of interaction have identified a significant number of interaction strategies employed by teachers in order to enhance students' discourse in EFL/ESL classrooms. Some researchers have found certain strategies to be more effective for developing students' discourse and promoting increased student talk (Meng and Wang, 2011; Walsh, 2002; Tsui, 1996; Walsh, 2006; Clifton, 
2006; Cullen 2002), and other strategies to be less effective or to have a negative impact on students' discourse. Studies concluded that extended wait-time, elicitation, negotiating meaning including clarification requests and confirmation checks, the use of back channels, and shaping students' responses tend to have a positive impact on enhancing students' discourse in EFL/ESL adult learners' classrooms (Meng and Wang, 2011; Walsh, 2002; Tsui, 1996; Walsh, 2006; Clifton, 2006; Cullen 2002). Whereas, turn interruption, turn completion, limited wait-time, and teacher's echo tend to have a less desirable and in some cases negative impact on students' discourse (Walsh, 2002; Yaqubi \& Rokni, 2012; Shamsipour \& Allami, 2012; Clifton, 2006). However, there is a disagreement on the effectiveness of teacher elaboration on students' responses and whether this strategy helps extend dialogue and encourages increased student talk, or is liable to limit students' opportunities to elaborate on their contributions. There is also some disagreement about how effective teacher echo is for enhancing students' verbal discourse in the EFL classroom.

\subsection{Summary}

EFL students' minimal contributions, reticence and very short responses were found to be a common problem faced by many EFL teachers. Some studies showed that different discourse strategies employed by teachers significantly impact students' classroom interaction and thus their language learning (Lee, 2009). Many researchers who examined patterns of classroom interaction, particularly the IRF/IRE structures in general, and who focused on the third turn of the IRF in particular, have provided evidence of the importance of teacher feedback or follow-up in developing students' contributions (Chin, 2006; Choudhary, 2005 and Hellermann, 2003). Finally, different studies have shown that the employment of a number of strategies when following students' responses can help develop the quality and quantity of student discourse.

\section{Methodology}

\subsection{Research Design and Paradigm}

Qualitative methods were adopted to accomplish this study's objectives accompanied by quantitative data which concerned the number of times each type of strategy is employed (Creswell, 2009). This research is centered in the interpretivist paradigm and it mainly underpins qualitative tools for data collection and analysis (Denzin \& Lincoln, 2003; Marshall \& Rossman, 2010 and Merriam, 2009). By taking a qualitative approach, utilizing an interpretivist focus, this research strives to serve as a means of enabling increased understanding of the impact of EFL teachers' interaction strategies on EFL students' contributions and classroom discourse. Crucially, it seeks to describe and clarify the manner in which the observed investigated contributions and classroom discourse are enhanced by the interaction strategies so employed.

\subsection{Participants}

The data was taken from nine male EFL classes; 150 Saudi male students and nine EFL male 
teachers in, in ELI at KAU (details of participant teachers' information are presented in Table 1. Students were randomly selected from two proficiency levels, (ELI 103 and ELI 104), from the second semester, in the academic year 2014/2015. The rationale for students' selection from these two levels is that ELI levels 103 and 104 Student Learning Outcomes (SLOs) are naturally more demanding and complex than the lower level SLOs (ELI 101 \& ELI 102) and the 103 and that 104 SLOs necessitate considerable amounts of classroom interaction.

Table 1. Participant Teachers' Information

\begin{tabular}{|c|c|c|c|}
\hline Teacher & Nationality & Qualification & Teaching Experience \\
\hline Teacher 1 & Pakistani & $\begin{array}{l}\text { Master's in English } \\
\text { Language \& Literature } \\
\text { (2002); MA TESOL in } \\
\text { progress; completed CELTA } \\
\text { in Sept, } 2012\end{array}$ & $\begin{array}{c}\text { 1-2 years EFL teaching at } \\
\text { adult/university level; } 11+\text { years } \\
\text { EFL at secondary level }\end{array}$ \\
\hline Teacher 2 & Egyptian & MA TESOL (2014) & $\begin{array}{l}\text { 5-7 years EFL teaching at } \\
\text { adult/university level }\end{array}$ \\
\hline Teacher 3 & Turkish & MA TESOL (2013) & $\begin{array}{c}11+\text { years EFL teaching at } \\
\text { adult/university level }\end{array}$ \\
\hline Teacher 4 & Tunisian & $\begin{array}{l}\text { Master's in Applied } \\
\text { Linguistics (2011) }\end{array}$ & $\begin{array}{c}\text { 3-4 years EFL teaching at } \\
\text { adult/university level; 1-2 years } \\
\text { EFL at secondary level; } 3-4 \\
\text { years' EFL at primary level. }\end{array}$ \\
\hline Teacher 5 & British & $\begin{array}{l}\text { Ph.D. in English (2014); } \\
\text { TEFL Certificate (2009) }\end{array}$ & $\begin{array}{c}\text { 11+ years EFL teaching at adult/ } \\
\text { university level; 5-7 years EFL } \\
\text { at secondary level. }\end{array}$ \\
\hline Teacher 6 & British & $\begin{array}{l}\text { PGCE Post Graduate } \\
\text { Certificate in Education } \\
(2005) ; \text { CELTA }(2005)\end{array}$ & $\begin{array}{l}\text { 8-10 years EFL teaching at } \\
\text { adult/university level. }\end{array}$ \\
\hline Teacher 7 & Indian & $\begin{array}{l}\text { BA Accounting \& Finance } \\
\text { (2002); CELTA (2006) }\end{array}$ & $\begin{array}{c}\text { 8-10 years EFL teaching at } \\
\text { adult/ university level; } 1-2 \text { years } \\
\text { EFL at secondary level. }\end{array}$ \\
\hline Teacher 8 & Tunisian & $\begin{array}{l}\text { MA in English (1997); } \\
\text { CELTA (2009) }\end{array}$ & $\begin{array}{c}\text { 11+ years EFL teaching at adult/ } \\
\text { university level }\end{array}$ \\
\hline Teacher 9 & Jordanian & $\begin{array}{l}\text { Master's in English } \\
\text { Language (2003) }\end{array}$ & $\begin{array}{c}\text { 5-7 years' EFL at } \\
\text { adult/university level; 3-4 years' } \\
\text { EFL at secondary level }\end{array}$ \\
\hline
\end{tabular}

\subsection{Data Collection Instruments}

Video and audio recordings, observation and note-taking were employed as data instruments. A total of ten hours of classroom discourse were recorded using a video camera installed at the back of the classes. A high-quality Sony audio recorder was positioned on the teacher's 
desk at the front to provide an additional source of data and to guarantee that both the teachers' and the students' voices are clearly audible. However, due the laws of the country, and impossibility to secure permission to audio or video record female instructors on the women's campus, physical observation of classroom interactions was replaced by observation of recorded videos, which allowed for repeated and meticulous minute by minute scrutiny of the observed interactions. While observing the recorded lessons, notes were taken using a comprehensive checklist of strategies of interaction employed by teachers to enhance students' contributions. The checklist included strategies such as echoing, reformulating, extending, and scaffolding next to a column for documenting the number of times each strategy was employed by each teacher. Comments were also written regarding these interactional strategies.

\subsection{Data Collection Procedures}

Data collection was conducted half way through the third seven-week module in the academic year 2014-2015. Data collection involved a total of ten hours of recordings from nine classrooms over an approximately two-week period. A total of twelve lessons were recorded, in which three of the nine teachers and their students were recorded twice. All students were requested to sign consent forms before attending the sessions and being video recorded. They were also informed that participation in this research is voluntary and assured that collected data will be dealt with confidentially.

\subsection{Data Analysis}

In order to address the aims of the current research, the Interaction Analysis (IA) approach was adopted for analyzing EFL classroom interaction data. More specifically, an 'ad hoc' interaction analysis approach was deemed to be suitable for analyzing EFL classroom discourse. ad hoc approaches "permit a finer grained understanding of a specific feature of the discourse" (Walsh, 2006, p.45). This research follows an ad hoc approach in analyzing the recorded data as the analysis is based on a number of strategies such as recapping, scaffolding, eliciting, giving clues, echoing: teacher-teacher echo, echoing: teacher-learner echo, extending, clarifying, using clarification requests, using confirmation checks, extending wait-time, reformulating, using comprehension checks, using backchannels, and translating. Before the analysis stage, all video recordings were transcribed by professional transcribers as opposed to computer-generated, using triple-pass quality assurance, in which initially a first draft transcription is produced, which is subsequently proofread. This proofread first draft is then sent to a supervisor for editing. The editing process involves the supervisor listening to the entire audio from start to finish for purposes of transcript verification. The transcripts were coded in terms of the fifteen strategies listed in the checklist, adding to and confirming the notes written while the videos were being observed. 14 extracts and 13 notes were further organized and entered in a separate Excel sheet in order to be used to help formulate appropriate responses to the two research questions. The qualitative analysis of teacher interaction strategies was supported by quantitative data. The quantitative data concerned the number of times each type of strategy is employed, while the qualitative analysis concerned the types of teacher interaction strategies employed for enhancing 
students' contributions. By relating teachers' interaction techniques to students' performance during classroom interaction, the researcher was able to see how teachers' interaction patterns impact students' verbal discourse in the EFL classroom setting. In order to ensure the validity of the current research, two trusted colleagues familiar with this research study were asked to independently read a third of the selected relevant transcripts and then read the relevant interpretations. This was performed for the purpose of examination and review, a strategy known as peer examination. At this stage, there was a high degree of concurrence between the analysis of this study and those of the other two reviewers, providing crucial evidence to enhance the validity of this qualitative research.

\section{Data Analysis and Results}

The qualitative analysis of teacher interaction strategies, together with a quantitative analysis of the number of times each strategy is used by each teacher reveals that echoing learners' responses and eliciting are the most common interaction strategies employed by teachers in the investigated Saudi EFL university classrooms. Other strategies are occasionally used by teachers for enhancing students' contributions, including reformulating, scaffolding, extending, and using backchannels. However, the collected data contains fewer instances of using confirmation checks, giving clues, teachers' echoing of their own utterances and clarifying. The analysis also reveals that clarification requests, extending wait-time, recapping and comprehension checks are rarely used by the EFL teachers in the study. Table 2 presents detailed information of the strategies used, and the number of times each strategy is employed by the nine participant teachers. It also details the total number and percentage of each interactional strategy.

Table 2. Teachers' Use of Classroom Interactional Strategies

\begin{tabular}{|c|c|c|c|c|c|c|c|c|c|c|c|c|c|c|}
\hline $\begin{array}{c}\text { Teacher } \\
\text { Interaction } \\
\text { Strategies }\end{array}$ & $\mathbf{T 1}$ & $\begin{array}{l}\mathrm{T} 2 \\
1^{\text {st }}\end{array}$ & $\begin{array}{l}\text { T2 } \\
2 \mathrm{n} \\
\text { d }\end{array}$ & $\begin{array}{l}\text { T3 } \\
\text { 1st }\end{array}$ & $\begin{array}{l}\text { T3 } \\
2^{\text {nd }}\end{array}$ & T4 & $\begin{array}{l}\text { T5 } \\
\text { 1st }\end{array}$ & $\begin{array}{l}\text { T5 } \\
\text { 2n } \\
\text { d }\end{array}$ & T6 & T7 & T8 & T9 & $\begin{array}{c}\text { Tot } \\
\text { al }\end{array}$ & $\%$ \\
\hline $\begin{array}{c}\text { Teacher-learner } \\
\text { echo }\end{array}$ & 21 & 19 & 3 & 22 & 17 & 30 & 47 & 25 & 51 & 12 & 29 & 62 & $\begin{array}{c}33 \\
8 \\
\end{array}$ & $\begin{array}{c}32.9 \\
\% \\
\end{array}$ \\
\hline Eliciting & 15 & 13 & 6 & 21 & 9 & 5 & 23 & 10 & 20 & 20 & 27 & 24 & $\begin{array}{c}19 \\
3\end{array}$ & $\begin{array}{c}18.8 \\
\%\end{array}$ \\
\hline Reformulating & 3 & 7 & 3 & 6 & 10 & 0 & 1 & 1 & 0 & 6 & 2 & 3 & 86 & $\begin{array}{c}8.4 \\
\%\end{array}$ \\
\hline Scaffolding & 3 & 1 & 4 & 5 & 9 & 5 & 15 & 8 & 4 & 1 & 3 & 5 & 63 & $\begin{array}{c}6.1 \\
\%\end{array}$ \\
\hline Extending & 2 & 4 & 4 & 0 & 7 & 1 & 0 & 0 & 3 & 10 & 8 & 23 & 62 & $\begin{array}{c}6.0 \\
\%\end{array}$ \\
\hline $\begin{array}{c}\text { Using } \\
\text { backchannels }\end{array}$ & 9 & 6 & 4 & 3 & 6 & 8 & 4 & 3 & 8 & 3 & 4 & 2 & 60 & $\begin{array}{c}5.8 \\
\% \\
\end{array}$ \\
\hline $\begin{array}{c}\text { Confirmation } \\
\text { Checks }\end{array}$ & 3 & 7 & 3 & 1 & 5 & 4 & 2 & 2 & 5 & 13 & 7 & 1 & 53 & $\begin{array}{c}5.2 \\
\% \\
\end{array}$ \\
\hline
\end{tabular}




\section{Macrothink}

\begin{tabular}{|c|c|c|c|c|c|c|c|c|c|c|c|c|c|c|}
\hline Giving clues & 4 & 0 & 5 & 5 & 5 & 10 & 2 & 1 & 9 & 0 & 7 & 0 & 48 & $\begin{array}{c}4.7 \\
\%\end{array}$ \\
\hline $\begin{array}{c}\text { Teacher-teache } \\
\text { r echo }\end{array}$ & 5 & 2 & 1 & 6 & 1 & 2 & 1 & 5 & 7 & 4 & 4 & 9 & 47 & $\begin{array}{c}4.6 \\
\%\end{array}$ \\
\hline Clarifying & 2 & 3 & 0 & 3 & 4 & 2 & 1 & 9 & 4 & 4 & 2 & 2 & 36 & $\begin{array}{c}3.5 \\
\%\end{array}$ \\
\hline $\begin{array}{c}\text { Clarification } \\
\text { Requests }\end{array}$ & 0 & 1 & 0 & 2 & 3 & 0 & 1 & 0 & 0 & 5 & 0 & 7 & 19 & $\begin{array}{c}1.9 \\
\%\end{array}$ \\
\hline $\begin{array}{c}\text { Extending } \\
\text { wait-time }\end{array}$ & 1 & 2 & 0 & 0 & 2 & 0 & 1 & 1 & 0 & 2 & 1 & 0 & 10 & $1 \%$ \\
\hline $\begin{array}{c}\text { Recapping } \\
\text { Comprehensio } \\
\text { n checks }\end{array}$ & 1 & 1 & 0 & 0 & 1 & 0 & 0 & 0 & 1 & 1 & 0 & 3 & 8 & 0.8 \\
\hline \begin{tabular}{c} 
Translating \\
\hline
\end{tabular} & 0 & 0 & 0 & 0 & 0 & 0 & 0 & 0 & 0 & 0 & 0 & 0 & 0 & $0 \%$ \\
\hline
\end{tabular}

Analysis of the video-recorded materials indicates that using these interactional strategies during classroom interaction has varying degrees of impact on students' spoken discourse. Strategies were classified into three categories; highly effective, effective and less effective strategies. The classification is based on whether the strategy almost always results in developing student discourse and increasing student engagement, or only sometimes has such effect.

Data revealed that eliciting, extending and using backchannels are the most effective strategies for enhancing student contributions. The analysis indicates that using elicitation strategies has a positive effect in increasing the amount of students' contributions and maximizing student interactional space. Students are encouraged to express their opinions and expand their participation following teachers' elicitation. In addition, extending proves to be one of the most effective strategies used by the observed EFL teachers. This is because the data shows that extending classroom interaction through asking additional questions on the topic of discussion results in increased numbers of students' turns, and encourages further student talk. Also, extending by means of the use of open-ended questions is seen as providing more opportunities for students' discourse contribution with longer talk, than are provided by the use of closed-ended questions. Finally, using backchannels, such as "uh-huh" and "okay", is also seen to be highly effective for developing student spoken discourse. The video recorded data shows that backchannels support students to complete and extend their talk. This in turn increases the amount and effectiveness of student classroom interaction, since backchannels also indicate that the teacher follows and understands what is being said. Whereas, scaffolding, clarifying, giving clues, and using clarification requests and confirmation checks are categorized as effective strategies due to their valuable role in improving student classroom discourse. Analysis reveals that using scaffolding techniques, through providing vocabulary support during classroom discussions, prompts learners to 
complete their turns and communicate their messages, thus facilitating discussion continuation. However, it has been found that teachers may need to repeat their scaffolding for other learners in order to create adequate support to promote students' interaction continuation. Furthermore, the use of clarifying patterns in which teachers clarify their own questions, requests, or problems through stressing some words or providing more details, has a positive effect on students' contributions. This strategy prompts learners to modify and develop their responses into more appropriate contributions, thereby helping increase student talk quantity. Similarly, giving clues for students by questioning or giving hints has a positive impact on students' contributions. This strategy helps improve the quality of students' responses as it encourages them to modify their talk. Other effective strategies include the use of clarification requests and confirmation checks which help in dialogue extension, as students are thereby encouraged to participate and produce more ideas. While clarification requests have an effective role in prompting learners to elaborate on their contributions, confirmation checks assist learners to modify contributions by rephrasing or altering their responses. On the other hand, results showed echoing, paraphrasing, recapping and extended wait-time are strategies with minimal or zero effect. Echoing, in which teachers repeat students' contributions, was mostly used to confirm and amplify students' responses and to indicate understanding. However, the data shows that this interactional pattern has an inconsequential neutral effect on students' discourse. This echoing strategy can be seen to neither help develop and extend student talk, nor impede student contributions. Another less effective strategy used by teachers in the Saudi setting is reformulating or paraphrasing of student contributions. Although reformulation is a valuable strategy used by teachers to present students' contributions in appropriate language without interrupting classroom discourse, this strategy does not seem to have an impact on students' verbal discourse, since it is not followed by students' modification or talk extension. Similarly, data demonstrates that recapping is a useful strategy used by some EFL teachers for clarifying and summarizing several opinions or contributions, and is usually not followed by any spoken student responses. Very few occasions show that this strategy may encourage students to participate as a result of teacher recapping of different ideas. Finally, the analysis of classroom talk showed that teachers' extended wait-time does not have any effect on students' spoken discourse, and that there are no reported differences in students' contributions when provided with an extended wait-time or a short time in which to respond. This indicates that lengthening wait-time duration does not necessarily lead to learners' enhanced or improved discourse.

\section{Discussion and Conclusion}

Data analysis answers the first research question, stating that: "What types of EFL verbal interaction strategies do teachers use in the ELI to enhance student contributions during classroom interaction?", by demonstrating that the nine participant teachers most frequently use echoing of students' responses and eliciting, in varying degrees, as discourse strategies during classroom interaction, in order to enhance students' contributions. This result coincides with Shamsipour and Allami's (2012) who found that EFL teachers use echoing of 
students' answers and questioning techniques more often than other strategies, categorizing eliciting as a positive feature of teacher talk and echoing as a negative feature. Other strategies which are occasionally employed by the majority of EFL teachers in the Saudi context include reformulating, scaffolding, extending and using backchannels. In addition, results reveal fewer instances of the use of confirmation checks, teachers' echoing of their own utterances, and clarifying strategies by the EFL teachers. Furthermore, teachers rarely use clarification requests, extended wait-time, recapping, and comprehension checks during classroom interaction to develop and encourage student talk. Similarly, Data analysis answers the second research question, stating that: "How do teachers' interaction strategies affect students' classroom verbal discourse?", by revealing that the use of different interactional patterns in the Saudi EFL classrooms has a varied impact on students' discourse during classroom interaction. The video-recorded classes in this study demonstrate that eliciting, extending and using backchannels are the most effective strategies used by teachers during the observed classroom interactions. These interaction strategies prompt learners to complete and/or extend their talk and help enhance the quality of their contributions. In addition to the aforementioned highly effective strategies, this study also reveals a number of other effective strategies for enhancing students' discourse. These include scaffolding, using clarification requests and confirmation checks, giving clues, teachers' echoing of their own utterance and clarifying. While the interaction strategies that are categorized as highly effective almost always result in developing EFL students' contributions, other strategies are classified as effective due to their efficacy in promoting increased student talk in some of the occasions in which they are used. In contrast to the strategies presented so far which have been shown to be either highly effective or effective, this research also sheds light on some strategies that had minimal or zero impact on students' verbal discourse. These include teacher echoing of student responses, reformulating, recapping, and extending wait-time. This study's results concerning echoing contradict with Allami's (2012) and Walsh's (2002). This contradiction could be due to the fact that on many of the occasions where such echoing is used in Saudi EFL university classes, the type of questions asked require very short answers and do not call for further student talk or elaboration, and thus there is little likelihood of the teacher echoing interfering or obstructing students' discourse.

To sum up, based on the discussion of the two research questions, the findings indicate that in the observed Saudi EFL class context, eliciting, extending and using backchannels are the most effective interaction strategies for enhancing students' contributions and expanding their interactional space. The discussion also shows that the participating EFL teachers employ effective and highly effective strategies more than the less effective strategies. Nevertheless, the findings reveal occasional use of extending and backchannels by teachers, which have considerable impact on promoting student contributions and extending their turns. Therefore, student verbal discourse is increasingly likely to be developed in Saudi EFL university classes by means of the use of a relatively higher amount of extending and backchannel strategies. From a sociocultural theory perspective, the findings of this study indicate that the observed EFL teachers are able to develop students' abilities to communicate in the target language by means of social interaction in the EFL classroom. The employment of the various observed interaction strategies within students' ZPD during classroom interaction is 
demonstrated as having a beneficial impact on the development of student classroom discourse.

\subsection{Pedagogical Implications}

Based on the findings of this study, the present study demonstrates the manner in which teacher talk, particularly the discourse strategies employed during classroom interaction, has an impact on EFL students' contributions and the development of their classroom discourse. EFL teachers should be cognizant of the various options available and ensure they are able to select appropriate interactional strategies in the interest of promoting student classroom interaction and increased student engagement. Moreover, teachers are required to be aware of the fact that strategies such as, eliciting, extending and using backchannels are vital tools for creating opportunities for students to participate and extend their classroom turns. Finally, teacher education programs would be well advised to devote increasing attention to specific language use and discourse patterns in the EFL classroom.

\subsection{Limitations of the Study}

The present study is limited to only Saudi male EFL participants and their teachers, and to data collection procedures,

\subsection{Recommendations for Future Study}

The following suggestions are identified for possible areas of investigation for future study:

1. Further research could be beneficially undertaken by exploring and investigating the type of strategies used by female teachers and their impact on Saudi female learners' discourse.

2. Replicating the study by investigating teachers' discourse strategies in other contexts and by including a wider range of participants in order to strengthen and validate this study's results.

3. Further research could profitably be conducted focusing exclusively on the impact of extending wait-time on developing students' contributions in the Saudi context to resolve the contradictions with other studies.

4. Investigating the impact of using different repair strategies on improving student talk and classroom interaction.

5. More research is needed to examine the usefulness of teacher echoing and whether it is more likely to encourage or impede students' classroom interaction. 


\section{Macrothink}

\section{References}

Adegbile, J., \& Alabi, O. (2005). Proficiency and communicative competence in L2: Implications for teachers and learners. International Journal of African \& African American Studies, 4(2), 31-37. Retrieved February 27, 2015 from https://ojcs.siue.edu/ojs/index.php/ijaaas/article/view/72

Aimin, L. (2013). The study of second language acquisition under socio-cultural theory. American Journal of Educational Research, 1(5), 162-167. https://doi.org/10.12691/education-1-5-3

Aljaafreh, A., \& Lantolf, J. P. (1994). Negative feedback as regulation and second language learning in the zone of proximal development. The Modern Language Journal, 78(4), 465483. https://doi.org/10.1111/j.1540-4781.1994.tb02064.x

Aljumah, F. H. (2011). Developing Saudi EFL students' oral skills: An integrative approach. English Language Teaching, 4(3), 84. https://doi.org/10.5539/elt.v4n3p84

Box, C. D. (2011). Microanalyzing discourse in the second and foreign language classrooms: A review of the literature. TESOL \& Applied Linguistics, 11(2), 1-14. Retrieved July 31, 2014 from http://journals.tc-library.org/index.php/tesol/article/viewFile/739/465

Brown, D. (2000). Principles of language learning and teaching. White Plains, NY: Addison Wesley Longman.

Brown, G. A., \& Wragg, E. C. (2003). Questioning in the secondary school. London: Routledge.

Chin, C. (2006). Classroom interaction in science: Teacher questioning and feedback to students' responses. International Journal of Science Education, 28(11), 1315-1346. https://doi.org/10.1080/09500690600621100

Choudhury, S. (2005). Interaction in second language classrooms. BRAC University Journal, 2(1), 77-82.

Clifton, J. (2006). Facilitator talk. ELT Journal, 60(2), 142-150. https://doi.org/10.1093/elt/cci101

Creswell, J. W. (2009). Research design: Qualitative, quantitative, and mixed methods approaches. Thousand Oaks, CA: SAGE Publications.

Cullen, R. (1998). Teacher talk and the classroom context. ELT Journal, 52(3), 179-187. Retrieved from http://eltj.oxfordjournals.org

Cullen, R. (2002). Supportive teacher talk: The importance of the F-move. ELT Journal, 56(2), 117-127. https://doi.org/10.1093/elt/56.2.117

Dagarin, M. (2004). Classroom interaction and communication strategies in learning English as a foreign language. English Language Overseas Perspectives and Enquiries (ELOPE) Journal, 1(1-2), 127-139. 


\section{Macrothink}

Denzin, N. K., \& Lincoln, Y. S. (2003). Introduction: The discipline and practice of qualitative research. In N. K. Denzin, \& Y. S. Lincoln (Eds.), Collecting and interpreting qualitative materials (pp. 1-28). Thousand Oaks, CA: Sage.

Hall, J. K., \& Walsh, M. (2002). Teacher-student interaction and language learning. Annual Review of Applied Linguistics, 22, 186-203. https://doi.org/10.1017/s0267190502000107

Hammonds, J., \& Gibbons, P. (2005). Putting scaffolding to work: The contribution of scaffolding in articulating ESL education. Prospect, 20(1), 6-30.

Hellermann, J. (2003). The interactive work of prosody in the IRF exchange: Teacher repetition in feedback moves. Language in Society, 32(01), 79-104. https://doi.org/10.23074169241

Jarvis, J., \& Robinson, M. (1997). Analysing educational discourse: An exploratory study of teacher response and support to pupils' learning. Applied Linguistics, 18(2), 212-228. Retrieved October 28, 2014 from http://applij.oxfordjournals.org

Johnson, K. E. (1995). Understanding communication in second language classrooms. Cambridge: Cambridge University Press.

John-Steiner, V., \& Mahn, H. (1996). Sociocultural approaches to learning and development: A Vygotskian framework. Educational Psychologist, 31(3-4), 191-206. Retrieved from http://webpages.charter.net/schmolze1/vygotsky/johnsteiner.html

Jones, S. L. (2011). Investigating the f-move in teacher talk: A south Korean study of teachers' beliefs and classroom practices. Unpublished MA thesis, University of Birmingham. Retrieved from http://www.birmingham.ac.uk/Documents/college-artslaw/cels/essays/mat efltesldissertations/Jonesdiss.pdf

Kim, M., \& Suh, C. (2004). Teacher talk in English classroom. English Language Teaching, 16(4), 181-204.

Kramsch, C. (1986). From language proficiency to interactional competence. The Modern Language Journal, 70(4), 366-372. https://doi.org/10.1111/j.1540-4781.1986.tb05291.x

Lee, W., \& Ng, S. (2009). Reducing student reticence through teacher interaction strategy. ELT Journal, 64(3), 302-313. https://doi.org/10.1093/elt/ccp080

Lemke, J. (1990). Talking science: Language, learning, and values. Norwood, NJ: Ablex.

Liu, M. (2005). Reticence in oral English language classrooms: A case study in China. TESL Reporter, 38(1), 1-16. Retrieved from https://journals.lib.byu.edu/spc/index.php/TESL/article/viewFile/3807/3553

Marshall, C., \& Rossman, G. B. (2010). Designing qualitative research. Thousand Oaks, CA: Sage.

Mehan, H. (1979). Learning lessons: Social organization in the classroom. Cambridge, MA: Harvard University Press. 
Meng, X., \& Wang, X. (2011). Action study of teacher's language on EFL classroom interaction. Theory and Practice in Language Studies, 1(1), 98-104. https://doi.org/10.4304/tpls.1.1.98-104

Mercer, N. (1992). Talk for teaching-and-learning. In K. Norman (Ed.), Thinking voices: The National Oracy Project (pp. 215-23). London, England: Hodder \& Stoughton.

Mercer, N. (1994). New-Vygotskyan theory and classroom education. In B. Stierer and J. Maybin (Ed.), Language, literacy and learning in educational practice (pp. 92-110), Clevedon, UK: Multilingual Matters.

Merriam, S. B. (2009). Qualitative research: A guide to design and implementation. San Fransico, CA: Jossey-Bass.

Mohr, K. J., \& Mohr, E. S. (2007). Extending English-language learners' classroom interactions using the Response Protocol. The Reading Teacher, 60(5), 440-450. Retrieved from http://www.colorincolorado.org/article/26871/

Mikkola, I. (2008). Teacher talk in the Finnish classrooms of English and the potential for communicative discourse. Unpublished MA thesis, University of Tampere. Retrieved from https://tampub.uta.fi/bitstream/handle/10024/78800/gradu02375.pdf?sequence=1

Moll, L. C. (1992). Vygotsky and education: Instructional implications and applications of sociohistorical psychology. Cambridge: Cambridge University Press.

Nassaji, H. \& Swain, M. (2000) A Vygotskian perspective on corrective feedback in L2: The effect of random versus negotiated help on the learning of English articles. Language Awareness, 9(1), 34-51. https://doi.org/10.1080/09658410008667135

Nassaji, H., \& Wells, G. (2000). What's the use of 'triadic dialogue'?: An investigation of teacher-student interaction. Applied Linguistics, 21(3), 376-406. https://doi.org/10.1093/applin/21.3.376

Nikula, T. (2007). The IRF pattern and space for interaction: Comparing CLIL and EFL classrooms discourse. In C. Dalton-Puffer \& U. Smit (Eds.), Empirical perspectives on CLIL classrooms discourse (pp. 179-204). Frankfurt: Peter Lang.

Nunan, D. (1991). Communicative tasks and the language curriculum. TESOL quarterly, 25(2), 279-295. https://doi.org/10.2307/3587464

Pei, M. (2012). Teacher's discoursal strategies in providing positive feedback to student responses: A study of four English immersion teachers in people's republic of China. International Education, 41(2), 110-126. Retrieved from http://trace.tennessee.edu/internationaleducation/vol41/iss $2 / 7$

Shamsipour, A. \& Allami, H. (2012). Teacher talk and learner involvement in EFL classroom: The case of Iranian setting. Theory and Practice in Language Studies, 2(11), 2262-2268. https://doi.org/10.4304/tpls.2.11.2262-2268

Shomoossi, N. (2004). The effect of teachers' questioning behavior on EFL classroom 


\section{Macrothink}

International Journal of English Language Education

ISSN 2325-0887

2017, Vol. 5, No. 2

interaction: A classroom research study. The Reading Matrix, 4(2), 96-104. Retrieved from http://www.idosi.org/hssj/hssj2(2)07/7.pdf

Sinclair, J., \& Coulthard, M. (1975). Towards an analysis of discourse. Oxford, England: Oxford University Press.

Snell, J. (1999). Improving teacher-student interaction in the EFL classroom: An action research report. The Internet TESL Journal, 5(4). Retrieved from: http://iteslj.org/Articles/Snell-Interaction.html

Tsui, A. B. M. (1995). Introducing classroom interaction. London: Penguin.

Tsui, A. B. M. (1996). Reticence and anxiety in second language learning. In K. Bailey \& D. Nunan (Eds.), Voices from the language classroom (pp. 145-167). New York: Cambridge University Press.

Tsui, A. B. M. (1998). The "unobservable" in classroom interaction. The Language Teacher, $22,25-26$.

van Lier, L. (1988). The classroom and the language learner. London, England: Longman.

Vygotsky, L. S.: Mind in Society: The development of higher psychological processes was published in English in 1978, Vygotsky, L. S. (1978). Mind in society: The development of higher psychological processes (M. Cole, V. John-Steiner, S. Scribner \& E. Souberman. Eds. (A. R. Luria, M. Lopez-Morillas \& M. Cole [with J. V. Wertsch], Trans.). Cambridge, Mass.: Harvard University Press. (Original manuscripts [ca. 1930-1934])

Walsh, S. (2002). Construction or obstruction: Teacher talk and learner involvement in the EFL classroom. Language Teaching Research, 6(1), 3-23. https://doi.org/10.1191/13621688021r095oa

Walsh, S. (2006). Investigating classroom discourse. London, England: Routledge.

Walsh, S. (2011). Exploring classroom discourse: Language in action. London, England: Routledge.

Walsh, S. (2012). Conceptualising classroom interactional competence. Novitas Royal, 6(1), 1-14. Retrieved August 4, 2014 from http://www.novitasroyal.org/Vol_6_1/Walsh.pdf

Walsh, S. (2013). Classroom discourse and teacher development. Edinburgh, England: Edinburgh University Press.

Walsh, S., \& Li, L. (2013). Conversations as space for learning. International Journal of Applied Linguistics, 23(2), 247-266. https://doi.org/10.1111/ijal.12005

Wells, G. (1999). Dialogic inquiry: Toward a sociocultural practice and theory of education. Cambridge: Cambridge University Press.

Willis, J. (1995). A recursive, reflective instructional design model based on constructivist-interpretivist theory. Educational Technology, 35(6), 5-23. 
Yanfen, L., \& Yuqin, Z. (2010). A study of teacher talk in interactions in English classes. Chinese Journal of Applied Linguistics, 33(2), 76-86. Retrieved from http://www.celea.org.cn/teic/90/10060806.pdf

Yaqubi, B., \& Rokni, M. P. (2012). Teachers' limited wait-time practice and learners' participation opportunities in EFL classroom interaction. Journal of English Language Teaching and Learning, 10, 127-160. Retrieved from https://www.academia.edu/3681679/Teachers_limited_wait-time_practice_and_learners_parti cipation_opportunities_in_EFL_classroom_interaction

Yoshida, H. (2008). An analysis of discourse in the EFL classroom. Osaka Kaidei Ronshu, 59(2), 1-14. Retrieved from http://www.i-repository.net/il/user_contents/02/G0000031 Repository/repository/keidaironshu_059_002_001-014.pdf

\section{Copyright Disclaimer}

Copyright for this article is retained by the author(s), with first publication rights granted to the journal.

This is an open-access article distributed under the terms and conditions of the Creative Commons Attribution license (http://creativecommons.org/licenses/by/3.0/). 